Review - Pregledni rad

UDK: 637.041

\title{
Potential health benefits of sphingolipids in milk and dairy products
}

\author{
doi: 10.15567/mljekarstvo.2016.0401 \\ Slavica Potočki \\ University School of Medicine, Department of Chemistry and Biochemistry, \\ Šalata 3, 10000 Zagreb, Croatia \\ Received - Prispjelo: 17.06.2016. \\ Accepted - Prihvaćeno: 20.10.2016.
}

\begin{abstract}
Sphingolipids are found in all eukaryotic and some prokaryotic cells. Milk and dairy products are one of the most important sources of sphingolipids. This compounds participate in a variety of indispensable metabolic, neurological, and intracellular signaling processes. Sphingolipids and their derivatives are highly bioactive compounds with anti-cancer, bacteriostatic and cholesterol-lowering properties. Therefore, this review focuses on the potential health benefits of the milk and dairy sphingolipids.
\end{abstract}

Key words: sphingolipids, sphingoid bases, gangliosides, milk, dairy products

\section{Introduction}

Milk and dairy products, which provide one third of the total daily intake, are one of the most important sources of sphingolipids. Sphingolipids are not "ordinary fats". They are better categorized as "functional ingredients" since they have not only structural, but also regulatory functions, and are effective already at low concentrations.

The health benefits of milk and fermented products have been known since medieval times. Milk is an important food in the human diet, not only as the sole source of nutrition for infants but also as a source of energy in the form of fat, protein and carbohydrate for children and adults. Directly transferred from the mother to the newborn, all the constituents of milk are in their natural state and adapted to bring energy and bioactive molecules. Milk from animals is also transformed into various dairy products for infant and adult human consumption. Aside from the nutritious value consisting of basic proteins, lipids and saccharides, milk contains also numerous biologically active substances, such as imunoglobulins, enzymes, antimicrobial peptides, oligosaccharides, hormones, cytokines and growth factors (Donovan, 2006; Pouliot and Gauthier, 2006; Tunick and Van Hekken, 2014).

\section{Milk lipids}

Milk contains about 3 to $5 \%(w / w)$ fat, but the absolute percentage of fat in milk varies according to multiple factors that include species, maternal diet and stage of lactation. Lipids contained in milk fat of mammals vary widely in content and composition (Jensen, 2002). Lipids are present in milk in the form of spherical entities of about 4 to $5 \mu \mathrm{m}$ diameter called milk fat globules, which are enveloped by a biological membrane known as the milk fat globule membrane (MFGM). This is highly complex biological membrane that surrounds the fat globule, hereby stabilizing it in the continuous phase of the milk, and preventing it from enzymatic degradation by lipases (Danthine et al., 2000). Many detailed investigations of the MFGM composition and structure 
(Figure 1) as well as it's technological, nutritional and health properties have been recently performed and reported in scientific reviews (Dewettinck et al., 2008; Gallier et al., 2012). Organization of the MFGM as a trilayer structure is now well accepted, with the inner layer composed of proteins and polar lipids from the endoplasmic reticulum and the outer bilayer of polar lipids originating from specialized secretory regions of the apical plasma membrane of the mammary epithelial cells (Heid and Keenan, 2005). The lipids of the MFGM are primarily polar lipids, although neutral lipids can also occur. The latter are triglycerides, diglycerides, monoglycerides, cholesterol and its esters. The polar lipids of the MFGM consist of phospho- and sphingolipids.

\section{Nature and characteristics of phospholipids}

Phospholipids are amphiphilic molecules with a hydrophobic tail and hydrophilic head group. The phospholipids found in most cell membranes are basically glycerophospholipids, which consists of fatty acids esterified to a glycerol backbone, a phosphate group and a hydrophilic residue (e.g. choline, ethanolamine, serine, and inositol). Thus, the MFGM is composed of phosphatidylcholine, phosphatidylethanolamine, phosphatidylinositol and phosphatidylserine. In addition to their structural roles, phospholipids participate in a variety of indispensable metabolic, neurological and intracellular signaling processes (Guo et al., 2005).
The backbone of phospholipids can also be the long chain amino-alcohol sphingosine instead of glycerol. These phospholipids are classified as sphingophospholipids, the most representative being sphingomyelin (Figure 2), consisting of sphingosine esterified to one fatty acid and phosphocholine.

Beside sphingophospholipids, the MFGM is composed of sphingolipids, such as gangliosides (Dewettinck et al., 2008; Lopez, 2011; Gallier et al., 2014).

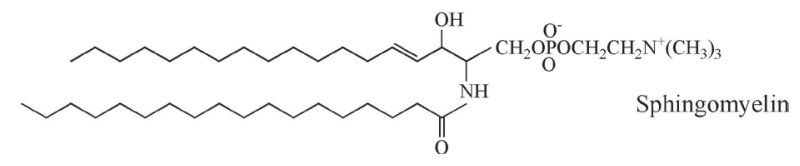

Figure 2. Structure of sphingomyelin

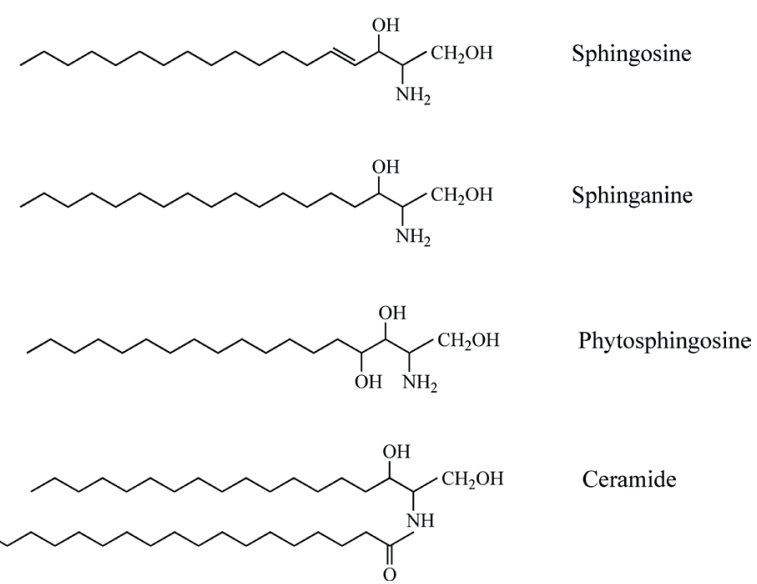

Figure 3. Structures of sphingoid bases and ceramide

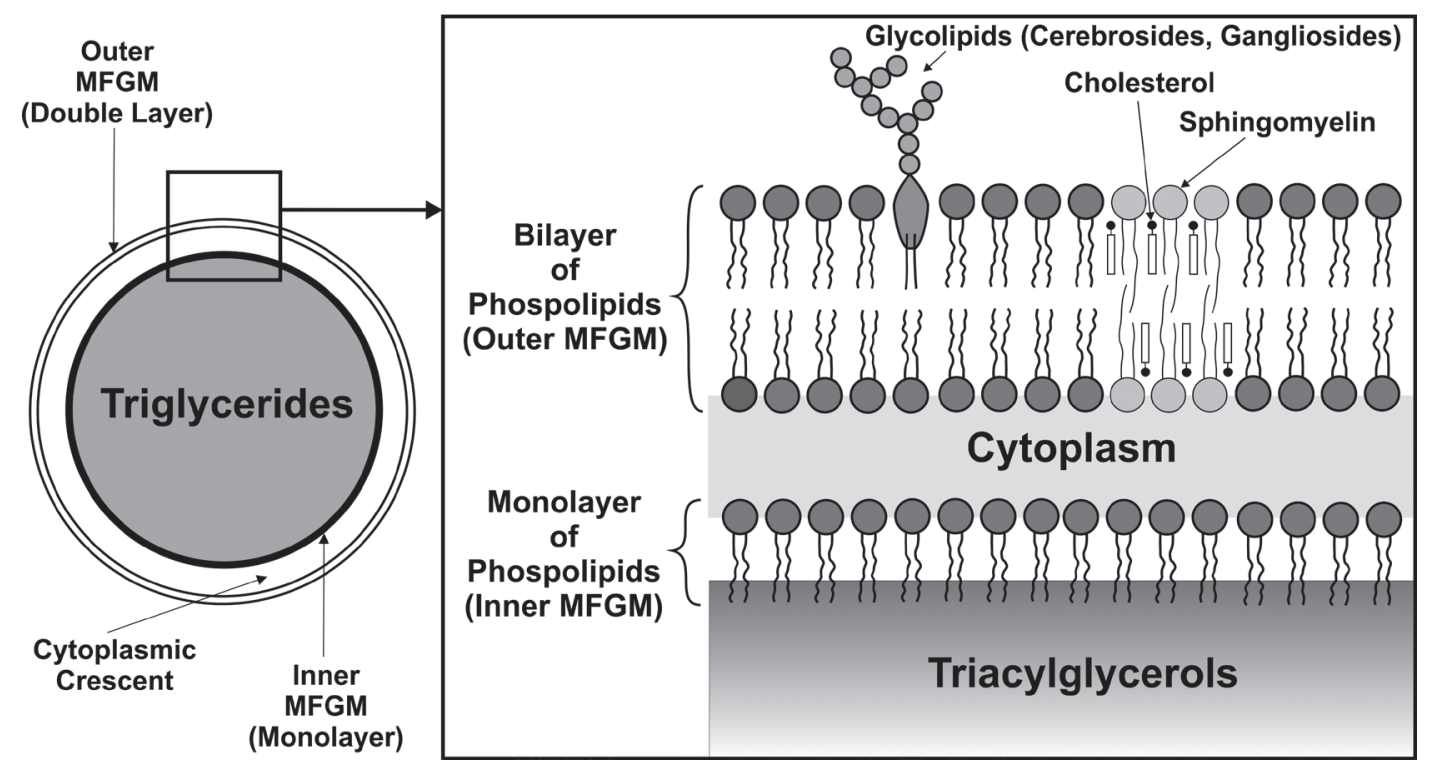

Figure 1. Structures of milk fat globule membrane 


\section{Sphingolipids}

Sphingolipids are ubiquitous lipids that were evolutionarily conserved among all eukaryotes. At the most basic level, they can be defined as any lipid molecule that contains the sphingoid backbone, derived from condensation of an amino acid (predominantly serine) and a fatty acid (predominantly palmitate) (Merrill, 2011). For many years, these molecules were considered structural components of biologic membranes; however studies over more than two decades have disclosed important biologic activities of many sphingolipids.

\section{Structure and classification}

The core of an SPL is an organic aliphatic amino alcohol, termed a sphingoid base. There are above 60 different sphingoid base backbones that vary in alkyl chain lenghts (Merrill, 2011), the degree of saturation and position of double bonds (Pruett et al., 2008) and the presence of a hydroxyl group (Hama, 2010). Mammalian organisms contain (Figure 3), mainly sphingosine (trans-4-sphingenine, d18:1D4), sphinganine (dihydrosphingosine, d18:0) and phytosphingosine (t18:0, 4-hydroxysphinganine) (Dickson, 2008). The presence or the absence of an acyl chain distinguishes ceramide from sphingosine (Figure 3), while phosphorylation of the 1-hydroxy group generates ceramide-1-phosphate or sphingosine-1-phosphate. Other common sphingolipids contain different headgroups at this position. due to the differing acyl CoAs that can be used to produce it, ceramide is technically a class of molecules rather than a single molecule and therefore may have different biological functions depending on the acyl chain it is composed of.

The most structurally diverse sphingolipids are glycosphingolipids which are produced from ceramide precursors, why they may differ in their acyl chain composition, revealing an additional layer of variation. The head group of glycosphingolipids always consists of one or more sugar residues attached to the 1-hydroxyl group. Cerebrosides are simple glycosphingolipids which have a hexose linked to the 1-hydroxyl position through a $\beta$-glycosidic bond. Physiologically important representatives of the cerebrosides are glucosyl- and galactosyl-ceramide. One of the most differentiated series are gangliosides, acidic glycosphingolipids with at least three sugars. One of them is sialic acid, also called $\mathrm{N}$-acetylneuraminic acid (Neu5Ac). Due to the large head group, the number of different gangliosides is correspondingly large.

Sphingolipids can be synthesized de novo by a single biosynthetic pathway, with the end product being ceramide (Bartke and Hannun, 2009).

Table 1. Sphingolipids content of different dairy products

\begin{tabular}{ccc}
\hline Sample & Sphingolipids (mg $100 \mathrm{~g}^{-1}$ product) & Reference \\
\hline Butter & 71,0 & Rombaut et al. (2006) \\
\hline Buttermilk & 19,0 & Rombaut et al. (2005) \\
\hline Cream & 49,0 & Rombaut et al. (2006) \\
\hline Skimmed milk & 6,0 & Rombaut et al. (2006) \\
\hline Swiss cheese & $8,4^{\mathrm{a}}$ & Ahn and Schroeder (2002b) \\
\hline Whey (Cheddar) & $5,0^{2}$ & Rombaut et al. (2005) \\
\hline Whey (Emmenthal) & $3,0^{\mathrm{b}}$ & Theodet and Gandemer (1994) \\
\hline Whey (Emmenthal) & $4,0^{\mathrm{b}}$ & Baumy et al. (1990) \\
\hline Whole milk & $4,9^{\mathrm{b}}$ & Christie et al. (1987) \\
\hline Yoghurt & $2,8^{\mathrm{a}}$ & Ahn and Schroeder (2002b) \\
\hline
\end{tabular}

${ }^{a} A$ conversion factor of $751 \mathrm{gmol}^{-1}$ was used

${ }^{\mathrm{b}} \mathrm{A}$ conversion factor of $1 \mathrm{~g} \mathrm{~mL}^{-1}$ was used 
Within the cells, sphingolipids are mainly found in the plasma membrane, the Golgi apparatus and in the lysosomes. Thus, sphingolipids can be expected in minor amounts in all food products.

\section{Sphingolipids in food}

Sphingolipids are present in nearly all foods and their amounts vary considerably. Milk and dairy products, which provide a third of the total intake, are one of the most important sources of sphingolipids (Table 1). Dairy products followed by meat and fish, eggs, and vegetables (Vesper et al., 1999). Based on a yearly per capita food consumption of $873 \mathrm{~kg}$, sphingolipids constitute from 0.01 to $0.02 \%$ of the diet (by weight). The quantities range from a few $\mu \mathrm{g} / \mathrm{kg}$ in fruit and some vegetables up to $1 \mathrm{~g} / \mathrm{kg}$ in dairy products, meat, eggs and soybeans (Vesper et al., 1999). As in many foods, sphingomyelin also accounts for the major portion of sphingolipids in dairy products. Sphingomyelin occupies a special place as a sphingophospholipid. Milk and dairy products contain around $0.3-1 \%$ of total fat as phospholipids. Approximately $60 \%$ of the total phospholipids in milk are found in the milk fat globule membrane. Some milk by products such as buttermilk and especially its MFGM fraction contain up to $40 \%$ (in weight) of phospholipids, of which $30 \%$ is phosphatidylethanolamine, $7 \%$ is phosphatidylinositol, $5 \%$ is phosphatidylserine, $31 \%$ is phosphatidylcholine, and $20 \%$ is sphingomyelin (Fong et al., 2007; Rodriguez-Alcala and Fontecha, 2010). The season and stage of lactation affect the sphingolipid content in the milk (Parodi, 1997). The content of membrane lipids, and consequently also sphingolipids, decreases along with lactation progress due to fewer presence of larger milk fat globules with thinner globule membrane (Bitman and Wood, 1990).

Structures of sphingolipids vary considerably with the type of food. In milk is mostly found sphingomyelin, but also a considerable amount of lactosylceramide, glucosylceramide, gangliosides (Jensen, 2002) and less amounts of sphingoid bases (Ribar et al., 2006; Ribar et al., 2007). Even more structural diversity is achieved by variations in the sphingoid base backbone and amide-bound fatty acids. These possible variations make sphingolipids structurally the most diverse class of membrane lipids.
Sphingolipids from food are most probably not essential for normal growth and development since most sphingolipids are synthesised de novo (Vesper et al., 1999). Nonethless both, complex sphingolipids and their digestion products (ceramides and sphingosines) as well are highly bioactive compounds with profaund effects on cell regulation. Sphingolipids from food cross the intestinal membrane and are biologically active, particularly in inhibiting colon carcinomas (Dillehy et al., 1994).

\section{Digestion and degradation of sphingolipids}

Before humans can actually utilise sphingolipids, they must be released from the food matrix by digestive enzymes. Dietary phospholipids and sphingolipids are not acted upon by lingual and gastric lipases, but the pancreatic one (occurring in in the intestinal lumen) does cleave fatty acids from their $s n$-2-position. Sphingomyelin leaves the stomach in a predominantly intact state and is first hydrolysed in the subsequent sections of the small and large intestine (Nyberg et al., 1997). The alkaline sphingomyelinase catalyses hydrolysis of sphingomyelin into ceramide and phosphocholine (Duan et al., 1995). Enzymatic activity of sphingomyelinase is low in the duodenum and reaches the highest level in the middle and lower parts of the small intestine (Nyberg et al., 1997; Duan et al., 1995). Subsequently, ceramides can be further hydrolyzed to sphingosine and fatty acid by ceramidase, which cleaves the amide bond. All of them then enter the enterocyte.

In many foodstuffs, glycosphingolipids occur in smaller quantities than sphingomyelin and are structurally more diverse. Degradation of glycosphingolipids occurs in the acidic compartments (lysosomes and endosomes) of the cell. Different hydrolases (depending on the sugar residue of the glycosphingolipid) cleave the sugar residues from the non-reducing end. The resulting mono saccharides, sialic acid, fatty acids and ceramides leave the lysosomes and are further degraded, absorbed or reintegrated into the sphingolipid cycle (Sandhoff and Kolter, 2003). Ceramide and sphingosine absorbed by the cells are either further broken down and become bioactive, or are again converted to complex sphingolipids (Merrill et al., 1995). 


\section{Sphingolipids activity}

For many years, sphingolipids were considered as structural components of biologic membranes. However studies performed over more than two decades disclosed important biologic activities of many sphingolipids. Sphingolipids are abundant in the apical membrane and in the absorptive epithelium in the gut (Danielsen and Hansen, 2006), while their digestion products (ceramides and sphingosine) are considered as the most bioactive compounds, having important effects on the cell regulation. Sphingolipids such as sphingosine, ceramide, sphingosine-1-phosphate have been implicated as modulators of physiologic and pathophysiologic processes such as cell growth, cell death, autophagy, angiogenesis, cell adhesion, differentiation, migration, senescence, intracellular trafficking, stress (Nikolova-Karakashian and Rozenova, 2010; Stancevic and Kolesnick, 2010) and inflammatory responses (E1 Alwani et al., 2006). Ceramide and sphingosine-1-phosphate (S1P) often exert opposing functions in the cell; as ceramide has been shown to mediate cell cycle arrest and cell death in response to cell stress (Hannun and Obeid, 2011), sphingosine-1-phosphate has been shown to promote cell survival and proliferation (Maceyka et al., 2009). Alterations in bioactive sphingolipids and their metabolism have been linked to several human diseases including cancer (Zeidan and Hannun, 2007; Furuya et al., 2011).

\section{Health benefits of dietary sphingolipids}

\section{Effects of sphingolipids on cancer}

Alongside classical pharmaceutical interventions to reduce the progression or the risk of several diseases, there is an increasing interest in nutraceuticals, or functional foods, as part of encouraging lifestyle intervention. There is no known nutritional requirement for sphingolipids in the diet. However, it has been reported that dietary supplementation with sphingolipids has diverse physiological benefits. Many in vitro and in vivo studies focused on the health effects of sphingolipids. Most research is centered on some cancers and neurological pathologies. Ceramides and sphingosine, the digestion products of sphingolipids, affect cell growth, differentiation and apoptosis, suggesting that their release may affect the behavior of normal or transformed cells, especially in the intestine (Duan and Nilsson, 2009). Dietary sphingolipids may be the key link connecting diet, inflammation and cancer (Canela et al., 2016). Sphingolipids may enhance or inhibit carcinogenesis, depending on their source and ability to be metabolized to sphingosine-1-phosphate (Degagne et al., 2014). The majority of "cancer and sphingolipids" studies concern colon cancer. The effect of dietary sphingolipids in colon cancer was actively studied both in vitro and in vivo. Evidence of the importance of dietary sphingolipids in fighting colorectal cancer was first described by Dudeja et al. (1986), who found differences in both sphingolipid composition and sphingolipid enzyme activities between tumor and normal tissue. Certain sphingolipids are also active against other cancer types, such as enigmol, a sphingoid base analog (Symolon et al., 2011). Sphingoid bases are cytotoxic for many cancer cell lines and are thought to contribute to suppression of intestinal tumorigenesis in vivo by ingested sphingolipids. Enigmol represents a novel category of sphingoid bases analogue that is orally bioavailable and has the potential to be effective against multiple types of cancer.

Sphingomyelin is one of the best-studied compounds in chemoprevention, ought to its roles as messenger in the development, growth, differentiation, and apoptosis of human cells. Therefore, several studies suggested its use in adjunct colon cancer treatment (Kuchta et al., 2012). In synthesis, sphingomyelin isolated from milk fat reduced the number of cryptic foci and prevented 1, 2-dimethylhydrazine-induced colon cancer in ICR rats and CF1 mice (Zhang et al, 2008; Dillehay et al., 1994). In colon cancer cells and mice models, sphingomyelin and glycosphingolipids from milk reduce the number of aberrant colonic crypt foci (Dillehay et al., 1994; Schmelz et al., 1996; Schmelz et al., 2000; Kurek et al., 2013). Milk-derived sphingomyelin also transformed adenocarcinomas to more benign adenomas (Schmelz et al., 1996) and exhibited chemopreventive and chemotherapic effects in CF1 mice (Lemonnier et al., 2003). Due to its content of long chain saturated fatty acids, sphingomyelin highly contributes to form, together with cholesterol, the rigid membrane domains, called "lipid rafts". Consequently, the regulation of the composition and density of lipid rafts could potentially alter cancer 
cell viability and metastatic behavior (Küllenberg et al., 2012). Non-pharmacological amounts of sphingomyelin in the diet showed chemopreventive and chemotherapeutic effects on chemically induced colon cancer in mice (Lemonnier et al., 2003). The chemopreventive effects of sphingomyelin appear to be due to its principal metabolites, i.e. sphingosine, sphingosine-phosphate, and ceramide, all of which induce apoptosis (Patwardhan et al., 2016).

Sphingoid bases and ceramide have been shown to induce apoptosis in colon cancer cells and suggested as potential mediators of the protective role of more complex dietary sphingolipids in colorectal cancer development (Ahn and Schroeder, 2002a). Ceramide production and its biological function are highly dependent on the length of the covalently linked fatty acid. The interplay between ceramides of various chain lengths seems to be crucial for cancer progression. Specific sphingolipids (and bioactive sphingolipid metabolites) together with changes in the expression and/or function of sphingolipidmetabolizing enzymes, could impact therapeutic response.

Altered sphingolipid composition was shown in colon cancer cells (Van Blitterswijk et al, 1984). There is increasing evidence that alteration in sphingolipid metabolism can modulate susceptibility to intestinal tumorigenesis. Indeed, dietary sphingolipids have both, chemopreventive and chemotherapeutic effects in colon cancer animal models. In addition, modulation of the enzymes implicated in sphingolipid metabolism seem to change the susceptibility to colon cancer formation as shown in the $\mathrm{SKl}^{-/-}$model following AOM/DSS treatment (Kawamori et al., 2009).

\section{Role of sphingolipids in binding and inactivation of toxins and bacteria}

It is well known that appropriate consumption of gangliosides through milk and other dairy products may protect from infections by binding and inactivating certain bacteria, viruses and their toxins (Rueda, 2007). Gangliosides which are profusely present on the surface of the apical membrane of enterocytes function as binding sites for bacteria and their toxins to prevent translocation of pathogens from the gut to the internal environment. Bacteria, viruses and toxins are inactivated after binding with glycosphin- golipids, and by exogenous sphingolipids (provided in diet) protect passage of the microorganisms through the intestinal mucosa. For example, bacterial toxins of Shigella and Escherichia or rotaviruses are bound and inactivated (Lafont et al., 2002; Lanne et al., 1995; Rolsma et al., 1998). Oral administration of gangliosides has resulted in the regresion of H. pylori infection (Miller-Podraza et al., 2004; Wada et al., 2010). S prong et al. (2001) reported that milk fat sphingomyelin and lyso-sphingolipids are potent anti-bacterial agents that increase resistance toward intestinal pathogens (E. coli, Salmonella enteritidis, Campylobacter jejuni, Listeria monocytogenes) mostly due to the medium-chain (C10:0 and C12:0) fatty acids of the lyso-derivatives. Haug et al. (2007) observed that gangliosides contained in MFGM modify the gastrointestinal receptor for microbial toxins, thereby partially preventing some digestive disorders. Proper gangliosides supplementation, for example, by consumption of milk, eggs, and other dairy products may protect from infections through binding and inactivation of bacterial toxins (Birecki et al., 2006; Rueda, 2007). Therefore, it can be concluded that dietary sphingolipids, particularly milk and egg gangliosides, may protect gut against infections through binding and inactivation of microbes and their toxins.

\section{Relation between dairy sphingolipids intake and cognitive function}

Few observational findings suggest that dairy food intake may be positively related to cognitive functions (Eskelinen et al., 2008; Vercambre et al., 2009; Park and Fulgoni, 2013). Sphingomyelin and sphingolipid metabolites are fundamental components in the central nervous system of myelin sheat that surrounds the axons of some neurons. A research on developing rats demonstrated that sphingolipids, especially sphingomyelin from milk, can contribute to the myelination of the central nervous system (Oshida et al., 2003). Tanaka et al. (2012) carried out a study on premature infants and showed that the administration of sphingomyelinfortified milk to the basis was positively associated with the neurobehavioral development. Recently, gangliosides have been associated with-enhancing spatial learning and affecting brain growth and composition in neonatal piglets (Liu et al., 2014). Studies focusing on dairy products-derived phospholipids 
showed that consumption of one glass of milk per day does improve cognitive function and memory in adults (Crichton et al., 2012). Recently, Park and Fulgoni (2013) observed better global cognitive function in adults and aged individuals who consumed milk goods as compared with those who abstained from such products.

Sphingolipids are associated with age-related diseases and the development of Alzheimer's disease (Parodi, 2001), as sphingolipid signalling may play a role in the progressive loss of cell function during the aging process. There are studies supporting the hypothesis that dietary phospholipids could contribute to the therapeutic approach to Alzheimer's disease, even if this is still a controversial issue.

\section{Effects of sphingolipids on lipid profile, cholesterol and cardiovascular risk}

Lipids, although essential for humans, were historically thought to elevate blood cholesterol and were therefore considered as dangerous to health. That attitude has been changing in recent years. Sphingolipids are involved in the intestinal uptake of cholesterol. Dietary sphingolipids supplementation could limit cholesterol-related diseases by inhibiting their absorption in intestinal mucosal cells (Kurek et al., 2013). Sphingomyelin was found to dose-dependently lower the intestinal absorption of cholesterol and fats in rats (Eckhardt et al., 2002; Noh and Koo, 2003). Sphingomyelin affects different aspects of cholesterol transport and metabolism suggesting that it may influence atherosclerosis (Vesper et al., 1999). Noh and Koo (2004) observed that milk sphingomyelin is more potent inhibitor of the intestinal absorption of cholesterol than egg sphingomyelin and this behavior can be explained by the higher degree of saturation and longer chain length of the fatty acyl groups. Duivenvoorden et al. (2006) reported that dietary sphingolipids play an important role in lowering plasma cholesterol and triacylglycerol and protecting the liver from fat- and cholesterol-induced steatosis. In addition, through the promotion of adiponectin signaling, dietary sphingolipids inhibit fatty liver, hipercholesterolemia, and insulin resistance (Yunoki et al., 2010; Bamba et al., 2012). It may be concluded that dietary sphingolipids hold great potential to treat multiple aspects of the metabolic syndrome, such as dyslipidemia, insulin resistance and cardiovascular diseases.
Effects of sphingolipids on the maintenance of skin homeostasis

Some studies indicate that the ingestion of sphingolipids, especially DHCer (dihydroceramide), confers beneficial effects for the restoration of permeability barrier dysfunction caused by ultraviolet (UV) B irradiation (Fukami et al., 2014). Russell et al. (2010) suggested that milk phospholipids, and in particular sphingomyelin, act upon skin cells protecting them against the effect of ultraviolet radiation. Studies on some cell types indicated that sphingolipids may have a protective activity even against damage from $\gamma$-irradiation and chemical agents (Vesper et al., 1999). Some studies have shown that GlcCer metabolism is essential to the maintenance of skin homeostasis (Takagi et al., 2005).

\section{Conclusions}

The public should be taught about the benefits of milk fat and of milk in general. Despite advertising and educational efforts, many consumers are still not fully aware that dairy foods are a good source of high quality ingredients. These efforts will have to be supported by further research on the mechanisms whereby milk components benefit humans. Although sphingolipids are probably not essential dietary components, they can make a contribution to human health (Figure 4). Unfortunately nutritional science is at the time insufficiently familiar with their use in practice, effect on the plasma sphingolipids level and the effective quantity of the sphingolipids ingested. As scientists continue to investigate food as it relates to health, people will realize the importance of dairy products in the diet.

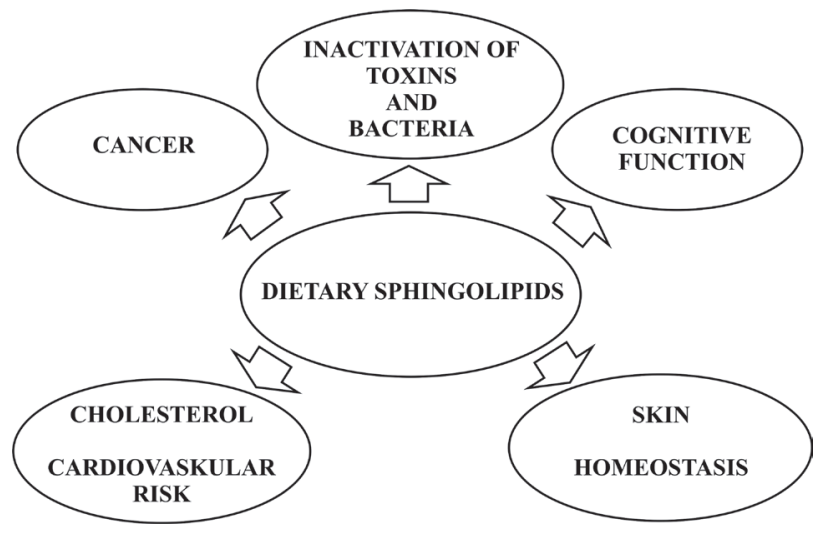

Figure 4. Health benefits of dietary sphingolipids 


\section{Potencijalne zdravstvene dobrobiti sfingolipida mlijeka i mliječnih proizvoda}

\section{Sažetak}

Sfingolipidi su prisutni u svim eukariotskim i nekim prokariotskim stanicama. Mlijeko i mliječni proizvodi su jedan od najvažnijih izvora sfingolipida. Sfingolipidi sudjeluju u raznim prijeko potrebnim metaboličkim, neurološkim i unutarstaničnim signalnim procesima. Oni i njihovi derivati su vrlo bioaktivni spojevi s anti-tumorskim i bakteriostatskim svojstvima, a djeluju i na snižavanje kolesterola. Stoga je ovaj pregled usredotočen na potencijalne zdravstvene dobrobiti sfingolipida mlijeka i mliječnih proizvoda.

\section{Ključne riječi: sfingolipidi, sphinzinske baze, gangliozidi, mlijeko, mliječni proizvodi}

\section{Explanation of abbreviation:}

MFGM = milk fat globule membrane

\section{References}

1. Ahn, E.H., Schroeder, J.J. (2002a): Sphingoid bases and ceramide induce apoptosis in HT-29 and HCT-116 human colon cancer cells, Experimental Biology Medicine 227 (5), 345-353.

2. Ahn, E.H., Schroeder, J.J. (2002b): Bioactive sphingolipids are constituents of soy and dairy products, Journal of Food Science 67, 522-524. doi: 10.1111/j.1365-2621.2002.tb10630.x

3. Bamba, T., Lee, J.W., Matsubara, A., Fukusaki, E. (2012): Metabolic profiling of lipids by supercritical fluid chromatography/mass spectrometry, Journal of Chromatography A 1250, 212-219. doi: 10.1016/j.chroma.2012.05.068

4. Bartke, N., Hannun, Y.A. (2009): Bioactive sphingolipids: metabolism and function, Journal of Lipid Research 50 (Suppl), 91-96. doi: 10.1194/j1r.R800080-JLR200

5. Baumy, J.J., Gestin, L., Fauquant, J., Boyaval, E., Maubois, J.L. (1990): Technologies de purification des phospholipides du lactoserum, Process 1047, 29-33.

6. Birecki, C.J., Drozdowski, L.A., Suh, M., Eek, J.P., Clandinin, M.T., Thomson, A.B.R. (2006): Dietary gangliosides enhance in vitro lipid uptake in weanling rats, Journal of Pediatric Gastroenterology and Nutrition 42 (1), 59-65. doi: 10.1097/01.mpg.0000187567.79633.a7
7. Bitman, J., Wood, D.L. (1990): Changes in milk fat phospholipids during lactation, Journal of Dairy Science 73, 1208-1216. doi: 10.3168/jds.S0022-0302(90)78784-X

8. Canela, N., Herrero, P., Marine, S., Nadal, P., Ras, M.R., Rodriguez, M.A., Arola, L. (2016): Analytical methods in sphingolipidomics: Quantitative and profiling approaches in food analysis, Journal of Chromatography A 1428, 16-38. doi: 10.1016/j.chroma.2015.07.110

9. Christie, W.W., Noble, R.C., Davies, G. (1987): Phospholipids in milk and dairy-products, Journal of the Society of Dairy Technology 40, 10-12. doi: 10.1111/j.1471-0307.1987.tb02385.x

10. Crichton, G., Howe, P.C., Buckley, J., Coates, A., Murphy, K. (2012): Dairy consumption and cardiometabolic health: outcomes of a 12-month crossover trial, Nutrition \& Metabolism 9, 1-11. doi: 10.1186/1743-7075-9-19

11. Danielsen, E.M., Hansen, G.H. (2006): Lipid raft organization and function in brush borders of epithelial cells, Molecular Membrane Biology 23, 71-79. doi: 10.1080/09687860500445604

12. Danthine, S., Blecker, C., Paquot, M., Innocente, N., Deroanne, C. (2000): Progress in milk fat globule membrane research: A Review, Lait 80, 209-222. doi: 10.1051/lait:2000120

13. Degagne, E., Pandurangan, A., Bandhuvula, P., Kumar, A., Eltanawy, A., Zhang, M. (2014): Sphingosine-1phosphate lyase downregulation promotes colon carcinogenesis through STAT3-activated microRNAs, Journal of Clinical Investigation 124, 5368-5384. doi: 10.1172/JCI74188

14. Dewettinck, K., Rombaut, R., Thienpont, N., Le, T.T., Messens, K., Van Camp, J. (2008): Review: Nutritional and technological aspects of milk fat globule membrane material, International Dairy Journal 18, 436-457. doi: 10.1016/j.idairyj.2007.10.014

15. Dickson, R.C. (2008): Thematic review series: Sphingolipids. New insights into sphingolipid metabolism and function in budding yeast, Journal of Lipid Research 49, 909-921. doi: 10.1194/jlr.R800003-JLR200

16. Dillehay, D.L., Webb, S.K., Schmelz, E.M., Merrill, A.H. (1994): Dietary sphingomyelin inhibits 1,2dimethylhydrazine-induced colon cancer incfl mice, Journal of Nutrition 124, 615-620.

17. Donovan, S.M. (2006): Role of human milk components in gastrointestinal development: current knowledge and future needs, Journal of Pediatrics 149 (Suppl. 1), S49-S61.

18. Duan, R.D., Nyberg, L., Nilsson, A. (1995): Alkaline sphingomyelinase activity in rat gastrointestinal-tract - Distribution and characteristics, Biochimca at Biophysica Acta 1259 (1), 49-55. doi: 10.1016/0005-2760(95)00137-2

19. Duan, R.D., Nilsson, A. (2009): Metabolism of sphingolipids in the gut and its relation to inflammation and cancer development, Progress in Lipid Research 48, 62-72. doi: 10.1016/j.plipres.2008.04.003 
20. Dudeja, P.K., Dahiya, R., Brasitus, T.A. (1986): The role of sphingomyelin synthetase and sphingomyelinase in 1,2-dimethylhydrazine-induced lipid alterations of rat colonic plasma membranes, Biochimica et Biophysica Acta 863 (2), 309-312. doi: 10.1016/0005-2736(86)90272-5

21. Duivenvoorden, I., Voshol, P.J., Rensen, P.C.N., Van Duyvenvoorde, W., Romijin, J.A., Emeis, J.J. (2006): Dietary sphingolipids lower plasma cholesterol and triacylglycerol and prevent liver steatosis in APOE 3 Leiden mice, American Journal of Clinical Nutrition 84, 312-321.

22. Eckhardt, E.R.M., Wang, D.Q.H., Donovan, J.M., Carey, M.C. (2002): Dietary sphingomyelin suppresses intestinal cholesterol absorption by decreasing thermodynamic activity of cholesterol monomers, Gastroenterology 122, 948-956. doi: 10.1053/gast.2002.32539

23. El Alwani, M., Wu, B.X., Obeid, L.M., Hannun, Y.A. (2006): Bioactive sphingolipids in the modulation of the inflammatory response, Pharmacology \& Therapeutics 112 (1), 171-183. doi: 10.1016/j.pharmthera.2006.04.004

24. Eskelinen, M.H., Ngandu, T., Helkala, E.L., Tuomilehto, J., Nissinen, A., Soininen, H., Kivipelto, M. (2008): Fat intake at midlife and cognitive impairment later in life: a population-based CAIDE study, International Journal of Geriatric Psychiatry 23, 741-747. doi: /10.1002/gps.1969

25. Fong, B.Y., Norris, C.S., MacGibbon, A.K.H. (2007): Protein and lipid composition of bovine milk-fat-globule membrane, International Dairy Journal 17, 275-288. doi: 10.1016/j.idairyj.2006.05.004

26. Fukami, H., Hatano, Y., Kishi, M., Katagiri, K., Fujiwara, S., Yamagimi, K. (2014): Ingestion of sphingolipids restores the skin permeability barrier after damage caused by repeated ultraviolet B irradiation in mice, Clinical and Experimental Dermatology 39, 71-72. doi: $10.1111 /$ ced.12162

27. Furuya,H.,Shimizu,Y.,Kawamori, T.(2011):Sphingolipids in cancer. Cancer Metastasis Reviews 30 (3-4), 567-576. doi: 10.1007/s10555-011-9304-1

28. Gallier, S., Gragson, D., Jimenez-Flores, R., Everett, D.W. (2012): $\beta$-Casein-phospholipid monolayers as model systems to understand lipid-protein interactions in the milk fat globule membrane, International Dairy Journal 22, 58-65. doi: 10.1016/j.idairyj.2011.08.007

29. Gallier, S., Laubscher, A., Jimenez-Flores, R. (2014): Chapter 4: The milk fat globule membrane: structure, methodology for its study, and functionality, in food structures, digestion and health, Food Structures, Digestion and Health, Elsevier Inc., pp 107-142. doi: 10.1016/b978-0-12-404610-8.00004-9

30. Guo, Z., Vikbjerg, A.F., Xu, X. (2005): Enzymatic modification of phospholipids for functional applications and human nutrition, Biotechnology Advances 23, 203-259. doi: 10.1016/j.biotechadv.2005.02.001
31. Hama, H. (2010): Fatty acid 2-hydroxylation in mammalian sphingolipid biology, Biochimica et Biophysica Acta 1801 (4), 405-414. doi: 10.1016/j.bbalip.2009.12.004

32. Hannun, Y.A., Obeid, L.M. (2011): Many ceramides, The Journal of Biological Chemistry 286 (32), 27855-27862. doi: 10.1074/jbc.R111.254359

33. Haug, A., Hostmark, A.T., Harstad, O.M. (2007): Bovine milk in human nutrition - a review, Lipids in Health and Disease 6, 1-16. doi: 10.1186/1476-511X-6-25

34. Heid, H.W., Keenan, T.W. (2005): Intracellular origin and secretion of milk fat globules, European Journal of Cell Biology 84, 245-258. doi: 10.1016/j.ejcb.2004.12.002

35. Jensen, R.G. (2002): The composition of bovine milk lipids: January 1995 to December 2000, Journal of Dairy Science 85, 295-350. doi: 10.3168/jds.S0022-0302(02)74079-4

36. Kawamori, T., Kaneshiro, T., Okumura, M., Maalouf, S., Flacker, A., Bielawski, J., Hannun, Y.A., Obeid, L.M. (2009): Role for sphingosine kinase 1 in colon carcinogenesis, FASEB Journal 23 (2), 405-414. doi: 10.1096/fj.08-117572

37. Kuchta, A.M., Kelly, P.M., Stanton, C., Devery, R.A. (2012): Milk fat globule membrane - a source of polar lipids for colon health? A Review, International Journal of Dairy Technology 65, 315-333. doi: 10.1111/j.1471-0307.2011.00759.x

38. Küllenberg, D., Taylor, L.A., Schneider, M., Massing, U. (2012): Health effects of dietary phospholipids, Lipids in Health and Disease 11, 1-16. doi: 10.1186/1476-511X-11-3

39. Kurek, K., Lukaszuk, B., Piotrowska, D.M., Wiesiolek, P., Chabowska, A.M., Zendzian-Piotrowska M. (2013): Metabolism, physiological role, and clinical implications of sphingolipids in gastrointestinal tract, BioMed Research International 2013, article ID908907. doi: http://dx.doi.org/10.1155/2013/908907

40. Lafont, F., van Nhieu, G.T., Hanada, K., Sansonetti, P., van der Goot, F.G. (2002): Initial steps of Shigella infection depend on the cholesterol/sphingolipid raft-mediated CD44-IpaB interaction, EMBO Journal 21 (17), 4449-4457. doi: 10.1093/emboj/cdf457

41. Lanne, B., Uggla, L., Stenhagen, G., Karlsson, K.A. (1995): Enhanced binding of enterotoxigenic Escherichia coli $\mathrm{K} 99$ to amide derivatives of the receptor ganglioside NeuGc-GM3, Biochemistry 34, 1845-1850. doi: 10.1021/bi00006a004

42. Lemonnier L.A., Dilleha, D.L., Vespremi, M.J., Abrams, J., Brody, E., Sch,elz, E.M. (2003): Sphingomyelin in the suppresion of colon tumors: prevention versus intervention, Archives of Biochemistry and Biophysics 419, 129-138. doi: http://dx.doi.org/10.1016/j.abb.2003.08.023 
43. Liu, H., Radlowski, E.C., Conrad, M.S., Li, Y., Dilger, R.N., Johnson, R.W. (2014): Early supplementation of phospholipids and gangliosides affects brain and cognitive development in neonatal piglets, Journal of Nutrition 144, 1903-1909. doi: 10.3945/jn.114.199828

44. Lopez, C. (2011): Milk fat globules enveloped by their biological membrane: unique colloidal assembles with a specific composition and structure, Current Opinion in Colloid \& Interface Science 16, 391-404. doi: 10.1016/j.cocis.2011.05.007

45. Maceyka, M., Milstien, S., Spiegel, S. (2009): Sphingosine-1-phosphate: the Swiss army knife of sphingolipid signaling, Journal of Lipid Research 50 (suppl), S271-S276.

46. Merrill, A.H., Schmelz, E.M., Wang, E., Schroeder, J.J., Dillehay, D.L., Riley, R.T. (1995): Role of dietary sphingolipids and inhibitors of sphingolipid metabolism in cancer and other diseases, Journal of Nutrition 125 (S6), 1677S-1682S.

47. Merrill, A.H. Jr. (2011): Sphingolipid and glycosphingolipid metabolic pathways in the era of sphingolipidomics, Chemical Reviews 111 (10), 6387-6422. doi: 10.1021/cr2002917

48. Miller-Podraza, H., Johansson, P., Angström, J., Larsson, T., Longard, M., Karlsson, K.A. (2004): Studies on gangliosides with affinity for Helicobacter pylori: Binding to natural and chemically modified structures, Glycobiology 14, 205-217. doi: 10.1093/glycob/cwh028

49. Nikolova-Karakashian, M.N., Rozenova, K.A. (2010): Ceramide in stress response, Advances in Experimental Medicine and Biology 688, 86-108. doi: 10.1007/978-1-4419-6741-1_6

50. Noh, S.K., Koo, S.I. (2003): Egg sphingomyelin lowers the lymphatic absorption of cholesterol and alpha-tocopherol in rats, Journal of Nutrotion 133, 3571-3576.

51. Noh, S.K., Koo, S.I. (2004): Milk sphingomyelin is more effective than egg sphingomyelin in inhibiting intestinal absorption of cholesterol and fat in rats, Journal of Nutrition 134, 2611-2616.

52. Nyberg, L., Nilsson, A., Lundgren, P., Duan, R.D. (1997): Localization and capacity of sphingomyelin digestion in the rat intestinal tract, Journal of Nutritional Biochemistry 8 (3), 112-118. doi: 10.1016/S0955-2863(97)00010-7

53. Oshida, K., Shimizu, T., Takase, M., Tamura, Y., Shimizu, T., Yamashiro, Y. (2003): Effects of dietary sphingomyelin on central nervous system myelination in developing rats, Pediatric Research 53, 589-593. doi: 10.1203/01.PDR.0000054654.73826.AC

54. Park, K.M., Fulgoni, V.L. 3rd. (2013): The association between dairy product consumption and cognitive function in the National Health and Nutrition Examination Survey, British Journal of Nutrition 109 (6), 1135-1142. doi: 10.1017/S0007114512002905

55. Parodi, P.W. (1997): Cow's milk fat components as potential anticarcinogenic agents, Journal of Nutrition 127 (6), 1055-1060.
56. Parodi P.W. (2001): Cow's milk components with anticancer potential, Australian Journal of Dairy Technology $56,65-73$.

57. Patwardhan, G.A., Beverly, L.J., Siskind, L.J. (2016): Sphingolipids and mitochondrial apoptosis, Journal of Bioenergetics and Biomembranes 48, 153-168. doi: 10.1007/s10863-015-9602-3

58. Pouliot, Y., Gauthier, S.F. (2006): Milk growth factors as health products: some technological aspects, International Dairy Journal 16, 1415-1420. doi: 10.1016/j.idairyj.2006.06.006

59. Pruett, S.T., Bushnev, A., Hagedorn, K., Adiga, M., Haynes, C.A., Sullards, M.C., Liotta, D.C., Merrill, A.H. Jr. (2008): Biodiversity of sphingoid bases ("sphingosines") and related amino alcohols, Journal of Lipid Research 49 (8), 1621-1639. doi: 10.1194/jlr.R800012-JLR200

60. Ribar, S., Karmelić, I., Mesarić, M. (2006): Sfingozinske baze u mlijeku, Mljekarstvo 56 (3), 255-268.

61. Ribar, S., Karmelić, I., Mesarić, M. (2007): Sphingoid Bases in Dairy Products, Food Research International 40, 848-854. doi: 10.1016/j.foodres.2007.02.003

62. Rodriguez-Alcala, L.M., Fontecha, J. (2010): Major lipid classes separation of buttermilk, and cows, goats and ewes milk by high performance liquid chromatography with an evaporative light scattering detector focused on the phospholipid fraction, Journal of Chromatography A 1217, 3063-3066. doi: 10.1016/j.chroma.2010.02.073

63. Rolsma, M.D., Kuhlenschmidt, T.B., Gelberg, H.B., Kuhlenschmidt, M.S. (1998): Structure and function of a ganglioside receptor for porcine rotavirus, Journal of Virology 72, 9079-9091.

64. Rombaut, R., Van Camp, J., Dewettinck, K. (2005): Analysis of phospho- and sphingolipids in dairy products by a new HPLC method, Journal of Dairy Science 88, 482-488. doi: 10.3168/jds.S0022-0302(05)72710-7

65. Rombaut, R., Van Camp, J., Dewettinck, K. (2006): Phospho-and sphingolipid distribution during processing of milk, butter and whey, International Journal of Food Science and Technology 41, 435-443. doi: 10.1111/j.1365-2621.2005.01091.x

66. Rueda, R. (2007): The role of dietary gangliosides on immunity and the prevention of infection, British Journal of Nutrition 98 (Suppl 1), S68-S73. doi: 10.1017/S0007114507832946

67. Russell, A., Laubscher, A., Jimenez-Flores, R., Laiho, L:H: (2010): Investigating the protective properties of milk phospholipids against ultraviolet light exposure in a skin equivalent model, Proceedings of SPIE 7569, 75692Z:1-75692Z:9.

68. Sandhoff, K., Kolter, T. (2003): Biosynthesis and degradation of mammalian glycosphingolipids, Philosophical Transactions of the Royal Society of London Series B-Biological Sciences 358 (1433), 847-861. doi: 10.1098/rstb.2003.1265 
69. Schmelz, E.M., Dillehay, D.L., Webb, S.K., Reiter, A., Adams, J., Merrill, A.H. (1996): Sphingomyelin consumption suppresses aberrant colonic crypt foci and increases the proportion of adenomas versus adenocarcinomas in CFl mice treated with 1,2-dimethylhydrazine: Implications for dietary sphingolipids and colon carcinogenesis, Cancer Research 56, 4936-4941.

70. Schmelz, E.M., Sullards, M.C., Dillehay, D.L., Merrill.A.H. (2000): Colonic cell proliferation and aberrant crypt foci formation are inhibited by dairy glycosphingolipids in 1,2-dimethylhydrazine-treated CFl mice, Journal of Nutrition 130, 522-527.

71. Sprong, R.C., Hulstein, M.F.E., Van der Meer, R. (2001): Bactericidal activities of milk lipids, Antimicrobial Agents and Chemotherapy 45 (4), 1298-1301. doi: 10.1128/AAC.45.4.1298-1301.2001

72. Stancevic, B., Kolesnick, R. (2010): Ceramiderich platforms in transmembrane signaling, $\begin{array}{llll}\text { FEBS Letters } & 584 & \text { (9), } & \text { 1728-1740 }\end{array}$ doi: 10.1016/j.febslet.2010.02.026

73. Symolon, H., Bushnev, A., Peng, Q., Ramaraju, H., Mays, S.G., Allegood, J.C., Pruett, S.T., Sullards, M.C., Dillehay, D.L., Liotta, D.C., Merrill, A.H. (2011): Enigmol: A novel sphingolipid analogue with anticancer activity against cancer cell lines and in vivo models for intestinal and prostate cancer, Molecular Cancer Therapeutics 10, 648-657. doi: 10.1158/1535-7163.MCT-10-0754

74. Takagi, Y., Nakagawa, H., Yaginuma, T., Takema, Y., Imokawa, G. (2005): An accumulation of glucosylceramide in the stratum corneum due to attenuated activity of beta-glucocerebrosidase is associated with the early phase of UVB-induced alteration in cuaneous barrier function, Archives of Dermatological Research 297, 18-25. doi: 10.1007/s00403-005-0567-7

75. Tanaka, K., Hosozawa, M., Kudo, N., Yoshikawa, N., Hisata, K., Shoji, H., Shinohara, K., Shimizu, T. (2012): The pilot study: sphingomyelin-fortified milk has a positive association with the neurobehavioural development of very low birth weight infants during infancy, randomized control trial, Brain Development 35, 45-52. doi: 10.1016/j.braindev.2012.03.004
76. Theodet, C., Gandemer, G. (1994): Fate of lipids during whey defatting process, Lait 74, 281-295.

77. Tunick, M.H., Van Hekken, D.L. (2014): Dairy products and health: Recent insights, Journal of Agricultural and Food Chemistry 63 (43), 9381-9388. doi: 10.1021/jf5042454

78. Van Blitterswijk, W.J., Hilkmann, H., Hengeveld, T. (1984): Differences in membrane lipid composition and fluidity of transplanted GRSL lymphoma cells, depending on their site of growth in the mouse, Biochimica et Biophysica Acta 778 (3), 521-529. doi: 10.1016/0005-2736(84)90403-6

79. Vercambre, M.N., Boutron-Ruault, M.C., Ritchie, K., Clavel-Chapelon, F., Berr, C. (2009): Long-term association of food and nutrient intakes with cognitive and functional decline: a 13-year follow-up study of elderly French women, British Journal of Nutrition 102, 419-427. doi: 10.1017/S0007114508201959

80. Vesper, H., Schmelz, E.M., Nikolova-Karakashian, M.N., Dillehay, D.L., Lynch, D.V., Merrill, A.H. (1999): Sphingolipids in food and the emerging importance of sphingolipids to nutrition, Journal of Nutrition 129 (7), 1239-1250.

81. Wada, A., Hasegawa, M., Wong, P.F., Shirai, N., Tan, L.J., Lianes, R., Hojo, H., Yamasaki, E., Inchinose, A., Inchinose, Y., Senba, M. (2010): Direct binding of gangliosides to Helicobacter pylori vacuolating cytotoxin (VacA) neutralizes its toxin activity, Glycibiology 20, 668-678. doi: 10.1093/glycob/cwq014

82. Yunoki, K., Renaguli, M., Kinoshita, M., Matsuyama, H., Mawatari, S., Fujino, T. Kodama, Y., Sugiyama, M., Ohnishi, M. (2010): Dietary sphingolipids ameliorate disorders of lipid metabolism in Zucker fatty rats, Journal of Agricultural and Food Chemistry 58, 7030-7035. doi: 10.1021/jf100722f

83. Zeidan, Y.H., Hannun, Y.A. (2007): Translational aspects of sphingolipid metabolism, Trends in Molecular Medicine 13 (8), 327-336. doi: 10.1016/j.molmed.2007.06.002

84. Zhang, P., Li, B., Gao, S., Duan, R.D. (2008): Dietary sphingomyelin inhibits colonic tumorigenesis with an upregulation of alkaline sphingomyelinase expresion in ICR mice, Anticancer Research 28, 3631-3635. 